\title{
Metode Pembelajaran Mind Mapping dan Musik Klasik terhadap Hasil Belajar Sejarah Siswa MAN
}

\author{
Ambar Sulianti'1, Sukma Nurwidiani' ${ }^{1}$, Siti Sarah Irvani Siregar1 \\ 1Fakultas Psikologi, UIN Sunan Gunung Djati Bandung
}

DOI: http://doi.org/10.29080/jpp.v11i1.363

\begin{abstract}
Since not all classrooms possible to support students' concentration, then student achievement was effected. This research aims to study the effectiveness of mind mapping and classical music to improve students' achievement in social studies especially history. This is an experimental research using pre-test and post-test control group design. Subjects are 100 MAN students who are divided into 3 groups in which group 1 as a control group studying history in a quiet room, group 2 using mind mapping, and group 3 having mind mapping and classical music in their learning process. Data were analyzed using the inferential analysis to see the differences between pre-test and post-test with the Kruskal Wallis test. The results showed that there was a significant improvement in student achievement in all three groups. Using mind mapping alone or a combination of mind mapping and classical music is effective as learning in a quiet room.
\end{abstract}

Key words : Mind mapping, Classical music, Learning outcomes

\begin{abstract}
Abstrak : Tidak semua ruangan kelas dapat kondusif menunjang konsentrasi belajar siswa sehingga berdampak kepada hasil belajar. Penelitian ini bertujuan menguji efektivitas mind mapping dan musik klasik terhadap peningkatan hasil belajar sejarah pada siswa MAN dalam kondisi ruangan berisik. Penelitian ini menggunakan metode eksperimen pre-test dan post-test dengan kelompok kontrol. Total 100 siswa MAN bertindak sebagai subjek penelitian, terbagi dalam 3 kelompok yaitu kelompok kontrol dalam ruangan hening, kelompok yang menggunakan mind mapping, serta kelompok yang menggunakan mind mapping dan musik klasik. Analisis inferensial digunakan untuk melihat perbedaan pre-test dan post-test dengan uji Kruskal Walls. Hasil penelitian menunjukkan bahwa terjadi peningkatan hasil belajar sejarah secara signifikan pada ketiga kelompok. Efektifitas peningkatan hasil belajar menggunakan mind mapping saja atau gabungan mind mapping dan musik klasik, sama dengan hasil belajar menggunakan ruangan hening.
\end{abstract}

Kata kunci : Mind mapping, Musik klasik, Hasil belajar

Corresponding Author: Ambar Sulianti (e-mail: ambarsulianti@uinsgd.ac.id) Fakultas Psikologi UIN Sunan Gunung Djati Bandung, Jl. A. H. Nasution 105 Bandung, Jawa Barat, Indonesia 40614 


\section{Pendahuluan}

Hasil belajar merupakan penilaian yang menggambarkan sejauh mana kemampuan siswa dalam mencapai tujuan pembelajaran. Salah satu indikator hasil belajar adalah kriteria ketuntasan minimal (KKM) yang mengukur daya serap siswa terhadap mata pelajaran yang dipelajari. Tercapainya tujuan pembelajaran tentunya dipengaruhi oleh kemampuan siswa dan kualitas pengajaran. Kualitas pengajaran yang dimaksud adalah profesionalitas dan keahlian yang dimiliki oleh guru dalam menggunakan strategi pembelajaran agar siswa dapat mencapai tujuan pembelajaran. Namun pada kenyataannya banyak siswa yang merasakan kesulitan memahami pelajaran dan mengeluhkan suasana pembelajaran yang monoton.

Berdasarkan penelitian pendahuluan, peneliti menemukan adanya masalah pada hasil belajar salah satu mata pelajaran di sekolah madrasah Aliyah di Kabupaten Bandung. Pada saat pembelajaran mata pelajaran sejarah di sekolah tersebut, siswa mengalami kesulitan dalam berkonsentrasi dan mengingat kembali pelajaran yang sudah diberikan. Berdasarkan wawancara dengan salah satu guru, didapatkan informasi bahwa siswa sering tidak menganggap serius mata pelajaran sejarah. Hal ini ditandai dengan tatapan kosong siswa yang terlihat seperti melamun, kesulitan dalam menjawab soal serta menangkap tugas yang diberikan oleh guru di kelas. Hal ini berdampak kepada banyak siswa tidak mencapai nilai Kriteria Ketuntasan Minimal (KKM) sehingga guru harus memberi tugas tambahan. Hasil wawancara awal pada siswa menunjukkan bahwa siswa merasa kesulitan fokus pada pelajaran sejarah karena merasa terganggu dengan suara kebisingan kelas lain yang menghafal mata pelajaran agama dan kebisingan dari lingkungan sekitar sekolah karena berlokasi di dekat pusat keramaian. Kesulitan fokus menyebabkan siswa tidak bisa mengingat apa yang disampaikan guru di kelas.

Kemampuan fokus dianggap sebagai bentuk pertahanan tingkat perhatian yang tinggi terhadap tugas yang diberikan (Mori, Naghsh, \& Tezuka, 2014). Upaya memfokuskan pikiran terhadap suatu objek tertentu dengan menyampingkan hal-hal yang tidak berhubungan disebut konsentrasi. Konsentrasi merupakan pemusatan perhatian dalam bentuk penguasaan dan penggunaan pengetahuan (Aviana \& Hidayah, 2015). Konsentrasi merupakan salah satu faktor yang mempengaruhi proses belajar. Konsentrasi dapat mengurangi perhatian yang terpecah dalam usaha individu memahami objek yang diperhatikan (Julianto, Dzulqaidah, \& Salsabila, 2014). Semakin tinggi konsentrasi siswa dalam belajar maka akan semakin efektif proses belajar yang dilaksanakan. Jika konsentrasi rendah maka hasil belajar yang diperoleh juga akan rendah (Halil, Yanis, \& Noer, 2015).

Berkonsentrasi dikatakan memiliki perhatian terfokus pada saat menghadapi tugas (Exercise \& Sport Psychology, 2014). Kemampuan fokus sangat dibutuhkan dalam memahami dan menghafal banyak konsep yang rumit dalam waktu singkat (Mori et al., 2014). Untuk dapat fokus, siswa memerlukan ruangan belajar yang tenang. Namun terkadang ruangan belajar siswa tidak memungkinkan untuk dibuat jauh dari kebisingan. Di dalam kelas, fokus siswa terbagi antara perhatian kepada guru dan suara-suara di luar kelas. Menurut Walberg dan Greenberg suasana kelas adalah penentu utama yang mempengaruhi proses belajar (Rohyatun, 2018). Perlu solusi membantu daya fokus siswa sehingga dapat meningkatkan hasil belajarnya meskipun dalam suasana bising.

Untuk dapat fokus, diperlukan ketenangan pikiran dan jiwa. Salah satu cara untuk memperoleh ketenangan adalah dengan mendengarkan musik instrumentalia, jenis musik tanpa ada suara orang bernyanyi. Jenis musik instrumentalia yang sering digunakan untuk menenangkan pikiran adalah musik klasik. Musik klasik memiliki perangkat musik yang beraneka ragam, sehingga di dalamnya terangkum warna-warni suara yang rentang variasinya sangat luas. Dengan kata lain variasi bunyi pada musik klasik jauh lebih kaya 
daripada musik lainnya sehingga musik klasik menyediakan variasi stimulasi yang sedemikian luas bagi pendengar.

Musik Klasik adalah suatu komposisi musik yang berasal dari kebudayaan Eropa sekitar tahun 1750-1825 silam. Dalam berbagai penelitian musik klasik memiliki pengaruh postif bagi yang mendengarkannya, di antaranya musik klasik dapat meningkatkan IQ di mana sebuah penelitian menunjukkan hasil bahwa anak-anak yang mengambil pelajaran musik menunjukkan kenaikan IQ. Selain itu musik klasik juga memiliki efek pada perkembangan memori yang membantu retensi dan keterampilan mendengar. Ketika mendengarkan musik klasik terjadi rangsangan pada jalur otak, yang memproses penalaran spasial (Panjaitan, 2020).

Musik-musik klasik memiliki keunggulan akan kemurnian dan kesederhanaan bunyi-bunyi yang dimunculkan. Irama, melodi, dan frekuensi tinggi pada musik Mozart merangsang dan memberi daya pada daerah-daerah kreatif dan motivasi dalam otak. Musik Mozart dan Beethoven memberi rasa nyaman tidak saja di telinga tetapi juga bagi jiwa yang mendengarnya. Gubahan-gubahan musik klasik ini, bila rajin diperdengarkan akan memberi efek keseimbangan emosi dan ketenangan (Kustap, 2006).

Beberapa teknik belajar-mengajar telah dikembangkan untuk melatih otak, salah satunya adalah mind mapping. Metode Mind Mapping (Peta Pikiran) adalah metode pembelajaran yang dikembangkan oleh Tony Buzan, kepala Brain Foundation. Mind mapping adalah metode mencatat kreatif yang memudahkan kita mengingat banyak informasi. Setelah selesai, catatan yang dibuat membentuk sebuah pola gagasan yang saling berkaitan, dengan topik utama di tengah, sementara subtopik dan perincian menjadi cabang-cabangnya. Cabang-cabang tersebut juga bisa berkembang lagi sampai ke materi yang lebih kecil. Mind mapping memiliki beberapa kelebihan yaitu menjadikan lebih kreatif, memusatkan perhatian, menyusun dan menjelaskan pikiran dengan lebih terarah, membantu belajar lebih cepat dan efisien (Buzan, 2006).

Tony Buzan sudah mengembangkan mind mapping lebih dari 30 tahun yang lalu sebagai metode pencatatan dan peringkasan yang memaksimalkan fungsi yang berbeda dari dua bagian otak. Sisi kiri otak bertanggung jawab atas kata-kata, logika, urutan dan analisis sementara sisi kanan melakukan tugas-tugas yang terkait dengan warna, emosi, bentuk dan imajinasi. Pemetaan pikiran menggunakan kedua sisi otak dan karenanya pemrosesan produktivitas akan meningkat yang diterjemahkan menjadi retensi yang lebih besar (Wilson, Copeland Solas, \& Guthrie-Dixon, 2016). Mind mapping mengarahkan siswa untuk menulis kata-kata yang memiliki hubungan dengan topik yang akan mereka diskusikan dengan menggunakan banyak cabang kata di sekitar topik. Siswa dilatih kreatif menulis kata-kata kunci di sekitar topik dan kemudian, dapat digunakan untuk memperluas ide siswa (Waloyo, 2017).

Berdasarkan kondisi kesulitan yang dihadapi siswa MAN dalam fokus pelajaran sejarah, diperlukan solusi pembelajaran dengan mengabaikan suara bising di luar kelas. Penelitian ini bertujuan menguji keefektifan metode mind mapping dan musik klasik dalam pembelajaran sejarah di MAN.

\section{Metode Penelitian}

Metode penelitian menguraikan bagaimana penelitian dilakukan atau menggambarkan prosedur penelitian yang terdiri atas rancangan atau desain penelitian, sasaran penelitian (populasi dan sampel), teknik pengumpulan data, dan teknik analisis data. Metode penelitian juga menjelaskan tentang bahan-bahan dan alat-alat yang digunakan, waktu, tempat, teknik, dan rancangan percobaan. 


\section{Desain Penelitian}

Penelitian ini merupakan penelitian eksperimen murni dengan desain PretestPostest Control Group Design. Di dalam desain ini dilakukan pretest yaitu tes yang dilakukan sebelum diberikan treatment. Setelah dilakukan treatment selanjutnya diberikan postest. Ada tiga kelompok dalam penelitian ini yaitu kelompok 1 belajar dalam kondisi hening tanpa suara, kelompok 2 melakukan pembelajaran dengan mind mapping, dan kelompok 3 menggunakan kombinasi mind mapping dan musik klasik.

\section{Subjek Penelitian}

Subjek penelitian dalam penelitian eksperimen ini adalah siswa MAN Bandung Kabupaten Bandung.

\section{Menentukan Besar Sampel}

Untuk menentukan besar sampel penelitian eksperimen, dilakukan penelitian pendahuluan untuk mendapatkan nilai standar deviasi dan target perbedaan dua pengukuran. Hasil penelitian pendahuluan pada 10 orang sampel disajikan pada table 1 berikut.

Tabel 1

Hasil Uji Coba Riset Pendahuluan

\begin{tabular}{ccccccccccccc}
\hline Subjek & A & B & C & D & E & F & G & H & I & J & Rerata & SD \\
\hline Pre-test & 1 & 5 & 6 & 4 & 3 & 2,5 & 6 & 2 & 8 & 1 & 3,85 & 2,51 \\
Post-test & 5 & 7 & 7 & 7 & 6 & 9 & 5 & 6 & 8 & 6 & 6,6 & 1,26 \\
\hline
\end{tabular}

Berdasakan tabel 1, diperoleh data bahwa:

$\mu_{0}=3,85 \pm 2,51$

$\mu_{a}=6,6 \pm 1,26$

Berdasarkan tabel $\mathrm{Z}$ diperoleh data:

$Z_{1-\alpha}=2,3266$

Power penelitian ini ditetapkan $90 \%=1,6499$

Adapun rumus untuk besar sampel minimal penelitian eksperimen adalah sebagai berikut:

$$
\begin{aligned}
n & =\frac{2 \sigma^{2}\left(Z_{1-\alpha}+Z_{1-\beta}\right)^{2}}{\left(\mu_{0}-\mu_{a}\right)^{2}} \\
& =\frac{2(2,51)^{2}(2,3266+1,6499)^{2}}{(3,85-6,6)^{2}} \\
& =\frac{(12,6)(15,8)}{7,56} \\
& =26,28 \\
& =27
\end{aligned}
$$

Dengan mempertimbangkan cadangan 10\%, maka jumlah sampel yang diambil adalah $n=$ $27+10 \% * 27$ (cadangan) $=27+3=30$ orang minimal jumlah orang per kelompok.

\section{Teknik Sampling}

Dalam penelitian eksperimen ini menggunakan teknik Double Sampling sebagai teknik sampling penelitian. Adapun langkah - langkah dalam menentukan sampel dengan Double Sampling sebagai berikut :

1. Membuat kocokan kelas pada tiap angkatan (kelas X, kelas XI, dan kelas XII)

2. Terambil kelas $\mathrm{X}$

3. Kocok kelas X (MIPA 1, MIPA 2, MIPA 3, IIS 1, IIS 2, IIS 3, IBB 1, dan IBB 2)

a. Terambil kelas MIPA $2=31$ orang (Kelompok Kontrol)

b. Terambil kelas MIPA $3=33$ orang (Kelompok Eksperimen 1)

c. Terambil kelas MIPA $1=36$ orang (Kelompok Eksperimen 2) 
Maka, 36 siswa untuk Kelompok Kontrol, 36 siswa untuk Kelompok Eksperimen 1, dan 37 siswa untuk Kelompok Eksperimen 2.

\section{Instrumen Penelitian:}

Mind mapping dibuat sendiri oleh siswa dengan dibimbing oleh tim peneliti. Materi yang diujikan berkaitan dengan sejarah kemerdekaan Indonesia. Tester memberikan gambar-gambar yang sekiranya membantu siswa untuk mengingat materi terkait. (Seperti gambar Presiden Soeharto, Rapat PPKI, Bendera China, PETA, Konferensi New York, dan kapal-kapal belanda yang di berhentikan di lautan Indonesia).

Musik klasik diperdengarkan menggunakan speaker yang disambungkan ke laptop. Musik klasik yang dipilih yaitu sebuah karya musik klasik dari Ludwig Van Beethoven yang berjudul Fur Elise.

Hasil belajar sejarah yang diujikan kepada subjek penelitian yaitu tes daya ingat materi sejarah yang harus dihafalkan selama 5 menit setelah pelajaran usai. Setelah menghafal selanjutnya siswa diperintahkan untuk mengisi 20 butir soal pilihan ganda yang mana soal-soal tesebut semuanya berkaitan dengan apa yang mereka hafalkan soalsoal tersebut dikerjakan dalam waktu 3 menit.

Peralatan dan bahan yang digunakan dalam penelitian ini adalah sebagai berikut:

1. Spidol berwarna dan alat tulis lainnya

2. Kertas karton putih (2 lembar)

3. Speaker

4. Mind mapping

5. Musik klasik (Beethoven - Fur Elise)

6. Soal - soal isian singkat

7. Teks bacaan tentang sejarah kemerdekaan Indonesia

\section{Prosedur Penelitian}

Pretest

Langkah-langkah melaksanakan penelitian eksperimen ini adalah sebagai berikut:

1. Subjek diberi materi sejarah selama 10 menit

2. Siswa diberi waktu untuk menghafalkan materi selama 7 menit.

3. Tester membagikan soal-soal isian singkat yang berkaitan dengan teks sejarah yang sebelumnya telah dibaca, soal sebanyak 10 butir.

4. Siswa diperintahkan untuk mengerjakan soal-soal tersebut selama 5 menit.

5. Seluruhnya dikerjakan dalam kondisi kelas bising dari luar.

\section{Post-test}

1. Sama dengan Langkah-langkah pada pre-test, namun dengan 3 macam kondisi.

2. Kelompok kontrol dilakukan dalam suasana hening tanpa keributan. (Pengambilan data dilakukan hari libur yaitu hari Sabtu )

3. Kelompok eksperimen 1, dilakukan dalam hari kerja dalam suasana keributan dibiarkan seadanya di luar kelas, tetapi di dalam kelas subjek menggunakan metode mind mapping.

4. Kelompok eksperimen 2, dilakukan dalam hari kerja dalam suasana keributan di luar kelas, tetapi di dalam kelas diperdengarkan musik klasik selama penelitian berlangsung dan menggunakan mind mapping.

Langkah-langkah pembuatan mind mapping (Nasih, 2014)

1. Mula-mula subjek dibimbing untuk memulai membuat mind mapping berawal dari bagian tengah kertas

2. Siswa diminta menulis ide utama dari materi sejarah yang dipaparkan, kemudian melingkupi dengan lingkaran.

3. Siswa menambahkan sebuah cabang yang keluar dari pusat pusatnya untuk setiap gagasan utama 
4. Untuk setiap cabang digunakan warna yang berbeda.

5. Pada setiap cabang ditulis kata kunci yang yang akan dikembangkan.

6. Ditambahkan simbol-simbol untuk mempermudah Ingatan dalam penulisan disarankan menggunakan huruf besar

\section{Analisis data}

Terdapat dua macam analisis inferensial yang digunakan. Yang pertama menggunakan uji t-test berpasangan untuk data berdistribusi normal dan Wilcoxon untuk data tidak berdistribusi normal dalam menganalisis perbedaan antara pre-test dan posttest masing-masing kelompok. Analisis kedua menggunakan Kruskal Walls untuk melihat apakah terdapat perbedaan signifikan antara kenaikan hasil belajar dari ketiga kelompok.

\section{Hasil Penelitian}

Data hasil peneltian pre-test dan post-test disajikan pada gambar 1.

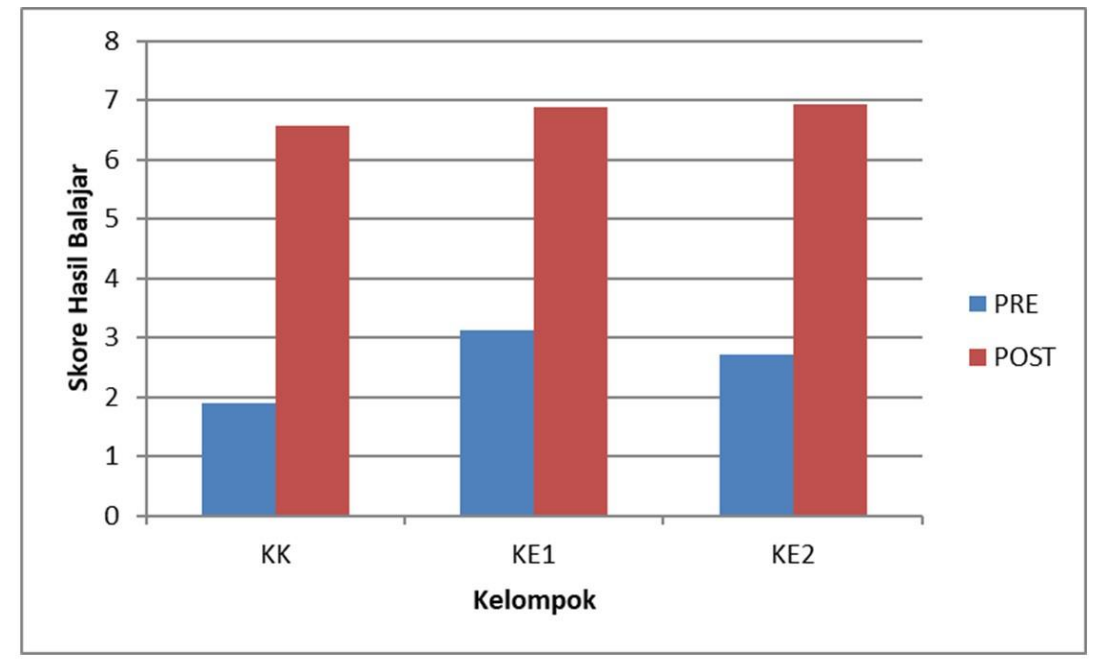

Gambar 1. Perbandingan Hasil Belajar pada Tiga Kelompok

Gambar 1 memperlihatkan terjadi peningkatan skor hasil belajar dalam mata pelajaran sejarah pada tiga kelompok. Untuk melihat signifikansi kenaikan hasil belajar pada masing-masing kelompok dilakukan uji sebaran normalitas data yang disajikan pada tabel 2.

Tabel 2

Distribusi Sebaran Data Hasil Belajar pada Kelompok Eksperimen dan Kontrol

\begin{tabular}{cccccc}
\hline \multirow{2}{*}{ Kelompok } & \multirow{2}{*}{ Rerata } & SD & \multicolumn{3}{c}{ Shapiro-Wilk } \\
\cline { 4 - 6 } & & & Statistik & df & Sig. \\
\hline Eksperimen 1 & 3,76 &, 919 & 33 &, 018 \\
Eksperimen 2 & 4,22 & 1,726 &, 924 & 36 &, 016 \\
Kontrol Hening & 4,68 & 1,815 &, 956 & 31 & 0,224 \\
\hline
\end{tabular}

Dari tabel di atas dapat diketahui bahwa pada kelompok kontrol, data berdistribusi normal karena p value $>$ taraf signifikan yaitu $0.224>0.05$, sedangkan pada kelompok eksperimen 1 (metode mind mapping) data berdistribusi tidak normal karena $p$ value $<$ taraf signifikan yaitu $0.018<0.05$ serta pada kelompok eksperimen 2 ( metode mind mapping dan musik klasik) juga berdistribusi tidak normal yaitu $p$ value $=0.016$ yang artinya bahwa $p$ value $<$ dari taraf signifikan $(0.016<0.05)$. Kelompok eksperimen 1 
memiliki rata-rata sebesar 3,76 dan standar deviasi sebesar 1,733 sedangkan dari kelompok eksperimen 2 memiliki rata-rata sebesar 4,22 dan standar deviasi sebesar 1,726 dan dari kelompok kontrol memiliki rata-rata sebesar 4,68 dan standar deviasi sebesar 1,815. Dari ketiga kelompok tersebut, pada kelompok kontrol memiliki rata-rata paling tinggi. Untuk melihat signifikasi perbedaan antara pre-test dan post-test dari masingmasing kelompok disajikan pada tabel 3.

Tabel 3

Hasil Uji Beda Masing-Masing Kelompok

\begin{tabular}{cccccc}
\hline \multirow{2}{*}{ Kelompok } & Rerata & Rerata & Uji Analisis & \multicolumn{2}{c}{ t atau Z Sig. } \\
\cline { 5 - 6 } & Pre-Test & Post-Test & Statistik & df & Sig. \\
\hline Eksperimen 1 & 3,121 & 6,879 & Wilcoxon & $-5,258$ & 0.000 \\
Eksperimen 2 & 2,722 & 6,944 & Wilcoxon & $-4,960$ & 0,000 \\
Kontrol hening & 1,903 & 6,581 & t-test berpasangan & -14.352 & 0,000 \\
\hline
\end{tabular}

Berdasarkan tabel di atas, pada seluruh kelompok terdapat peningkatan hasil belajar secara signifikan. Untuk mengetahui signifikansi perbedaan antar kelompok dilakukan uji Kruskal Walls yang disajikan pada tabel 4.

Tabel 4

Analisis Kruskal Walls

\begin{tabular}{cccc}
\hline Kelompok & N & $\begin{array}{c}\text { Rerata } \\
\text { Rank }\end{array}$ & Sig \\
\hline Eksperimen 1 & 33 & 43,95 & \\
Eksperimen 2 & 36 & 50,74 & \\
Kontrol hening & 31 & 57,19 & 0,179 \\
\hline
\end{tabular}

Hasil analisis Kruskal Walls menunjukkan peningkatan hasil belajar antara kelompok kontrol dalam suasana hening, kelompok eksperimen 1, dan eksperimen 2 tidak berbeda signifikan.

\section{Pembahasan}

Hasil penelitian ini menunjukkan bahwa baik dengan memberikan treatment suasana hening, mind mapping, mind mapping dan musik klasik, ketiganya meningkatkan hasil belajar sejarah secara signifikan. Kontrol standard suasana hening ditujukan untuk menjadi acuan hasil belajar sesuai standard kondisi ruangan. Eksperimen 1 dan 2 dilakukan dalam suasana tetap berisik di luar kelas karena pada praktiknya, tidak memungkinkan untuk membuat suasana hening dalam proses belajar mengajar di sekolah tersebut. Hasil penelitian ini menunjukkan tidak berbeda signifikan peningkatan hasil belajar sejarah baik dengan suasana hening, maupun suasana berisik yang menggunakan metode mind mapping dan kombinasi mind mapping - musik klasik.

Konsep mind mapping adalah sebuah metode ilustratif yang menggambarkan ideide yang terhubung dengan topik sentral. Fitur klasik dari metode pembelajaran aktif ini adalah representasi informasi ide dan konsep dalam bentuk teks pendek dan hubungan mereka diwakili melalui garis-garis yang saling berhubungan mulai dari topik tekstual sentral "di atas kertas". Sub-topik lebih lanjut atau ide-ide yang terkait dapat ditambahkan secara berulang ke topik-topik utama untuk diungkapkan misalnya hierarki informasi, dan garis interkoneksi lebih lanjut dapat ditarik melintasi bagian-bagian peta pikiran yang berbeda sesuai kebutuhan (Dirnberger, 2016). Metode mind mapping mempunyai banyak keunggulan, dua di antaranya adalah dengan mind mapping ide permasalahan 
diidentifikasi secara jelas dan mind mapping membuat kita lebih mampu berkonsentrasi pada permasalahan yang sering dihadapi.

Mind mapping dapat mengembangkan kemampuan siswa dalam menghafal, bertukar pikiran, belajar, serta kreativitas (Suryani, M. Syauqi, 2017). Mind mapping memiliki peran penting untuk membantu siswa dalam mengeksplorasi pengetahuan mereka tentang cerita, sehingga merangsang otak siswa untuk mengingat ingatan mereka yang terkait dengan keseluruhan cerita (Waloyo, 2017). Dengan demikian untuk mata pelajaran sejarah, mind mapping membantu subjek dalam menghafal rangkaian kisah sejarah. Mind mapping adalah aplikasi yang memberi otak informasi yang bermakna untuk dipahami dengan cara yang sederhana. Teknik mind mapping mempersiapkan pikiran sedemikian rupa sehingga informasi dapat digunakan secara logis dan imajiner untuk membuat gambar di otak. Dalam teknik mind mapping. Metode ini cocok untuk guru dan siswa untuk pengulangan dan topik sulit yang mudah dipahami (Parikh, 2016). Tony Buzan mendefinisikan pemetaan pikiran sebagai ekspresi dari pemikiran radioaktif, dan karena itu merupakan fungsi alami dari pikiran manusia. Ini adalah teknologi grafis yang sangat berguna, adalah kunci utama untuk membuka potensi otak (Hu \& Yu, 2016).

Penggunaan mind mapping dalam pendidikan mendukung peningkatan konsep penghafalan. Ditemukan bahwa mind mapping adalah cara kreatif bagi siswa untuk terlibat dalam metode pembelajaran unik yang dapat memperluas daya ingat topik-topik utama dan membantu menciptakan lingkungan baru untuk memproses informasi (Wilson et al., 2016). Strategi mind mapping mengharuskan siswa untuk menggunakan keterampilan berpikir kreatif mereka. Siswa harus dapat menentukan ide utama suatu bahan, kata kunci yang sesuai, menggunakan perpaduan warna yang tepat dan juga dapat menggunakan simbol yang dapat meningkatkan daya ingat mereka (Susanti, Poedjiastoeti, \& Taufikurohmah, 2018). Mind mapping merupakan organisator grafik di mana kategori utama memancar dari gambar pusat dan kategori yang lebih rendah digambarkan sebagai cabang dari cabang yang lebih besar yang dapat digunakan untuk menghasilkan ide, membuat catatan, mengembangkan konsep dan ide, dan meningkatkan daya ingat (Al-Jarf, 2015).

Hasil penelitian ini menunjukkan bahwa peningkatan hasil belajar pada kelompok yang mendapatkan perlakukan mind mapping dan musik klasik lebih tinggi dari pada kelompok yang diberikan mind mapping saja. Hal ini sejalan dengan penelitian Ramadhona bahwa kombinasi mind mapping dan musik klasik meningkatkan motivasi belajar yang pada akhirnya meningkatkan hasil belajar pada matematika (Ramadhona, 2016).

Musik klasik mempunyai fungsi menenangkan pikiran dan katarsis emosi, serta dapat mengoptimalkan tempo, ritme, melodi dan harmoni yang teratur dan dapat menghasilkan gelombang alfa serta gelombang beta dalam gendang telinga sehingga memberikan ketenangan yang membuat otak siap menerima masukan baru, efek rileks dan menidurkan (Annastacia, 2016). Selain itu musik klasik berfungsi mengatur hormonehormon yang berhubungan dengan stres antara lain ACHT, prolaktin, dan hormon pertumbuhan serta dapat mengurangi nyeri (Campbell, 2001). Oleh karenanya, musik yang dapat menjadi stimulus suasana hati akan sangat dibutuhkan dalam lingkungan belajar untuk memfasilitai proses mengingat kembali. Musik terbukti bisa menciptakan suasana yang dibutuhkan seseorang, beberapa tahun yang lampau, Terry Woodford, seorang produser musik grup Temptations dancSupremes, memproduksi rekaman laguc Baby Go to Sleep (ninabobo) dan memberikan rekaman itu secara gratis ke 15- pusatpusat penitipan anak dan beberapa rumah sakit. Hasilnya adalah, rekaman tersebut mampu menenangkan bayi dan anak-anak. Di Hellen Keller Hospital di Albama, menemukan bahwa 94\% bayi-bayi yang menangis segera tertidur tanpa botol susu dan empeng apabila di perdengarkan musik klasik. Seorang bayi yang hampir meninggal 
karena pemulihan operasi jantung di University of Albama, Birmingham, langsung menjadi tenang, dan bertahan hidup saat di perdengarkan klasik (Campell, 2002).

Sebuah penelitian mengatakan bahwa musik sangat penting dalam proses recall dan memperkuat persepsi pada kampanye politik (Wardan, 2017). Bahkan, kebiasaan mendengarkan musik sebelum tidur bisa membantu dalam meningkatkan kemampuan memori atau daya ingat (Born,2013). Musik dapat menjadi sarana untuk meningkatkan semangat siswa dalam memacu daya ingat (Carr, 2016). Rangsangan ritmis dari musik yang diperdengarkan juga dapat meningkatkan kemampuan berbahasa, meningkatkan kreativitas, serta meningkatkan konsentrasi dan daya ingat (Campbell, 2002). Musik adalah seni yang ajaib, karena musik bisa mempengaruhi orang saat mendengarkannya. Beberapa teori menunjukan bahwa informasi yang dipelajari dalam suasana hati yang khusus dan di asosiasikan dengan stimulus emosi akan lebih mudah iingat.

\section{Simpulan dan Saran}

Metode pembelajaran mind mapping dan kombinasi mind mapping-musik klasik meningkatkan hasil belajar sejarah pada siswa MAN. Efektifitas peningkatan hasil belajar menggunakan mind mapping saja atau gabungan mind mapping dan musik klasik, sama dengan hasil belajar menggunakan ruangan hening. Disarankan untuk sekolah MAN yang tidak memungkinkan untuk mengkondisikan ruangan hening, pembelajaran dilakukan dengan menggunakan metode mind mapping dengan atau tanpa diiringi musik klasik.

\section{Daftar Pustaka}

Al-Jarf, R. (2015). the Journal of Teaching English for Specific and Academic Purposes a Model for Enhancing Efl Freshman Students' Vocabulary With Mind-Mapping Software. 3(3), 509-520.

Aviana, R., \& Hidayah, F. F. (2015). Pengaruh Tingkat Konsentrasi Belajar Siswa terhadap Daya Pemahaman Materi pada Pembelajaran Kimia di SMA Negeri 2 Batang. Jurnal Pendidikan Sains (JPS), 3(1), 30-33.

Campbell, D. G. (2001). Efek mozart. Gramedia Pustaka Utama.

Dirnberger, D. (2016). The use of mindmapping software for patent search and management. World Patent Information, 47, 12-20. https://doi.org/10.1016/j.wpi.2016.08.004

Exercise \& Sport Psychology. (2014). SPORTPSYCH WORKS. Concentration and Attention in Sport, 2(1), 1-2.

Halil, A., Yanis, A., \& Noer, M. (2015). Pengaruh Kebisingan Lalulintas terhadap Konsentrasi Belajar Siswa SMP N 1 Padang. Jurnal Kesehatan Andalas, 4(1).

Hasan, A. (2005). Kamus Besar Bahasa Indonesia. Jakarta: Departemen Pendidikan Nasioanal Balai Pustaka

Hu, D.-H., \& Yu, X.-J. (2016). Construct Primary Education Semantic Ontology Library Based Mind Mapping. ITM Web of Conferences, 7, 04010. https://doi.org/10.1051/itmconf/20160704010

Julianto, V., Dzulqaidah, R. P., \& Salsabila, S. N. (2014). Pengaruh mendengarkan murattal Al Quran terhadap peningkatan kemampuan konsentrasi. Psympathic: Jurnal Ilmiah Psikologi, 1(2), 120-129.

Kustap, K. (2006). Musik Klasik Mozart Dan Beethoven Suatu Refleksi Konsep Estetika Plato (the Clasical Music of Mozart and Bethoven a Reflection of Platoâ€TM s Aesthetic Concept). Harmonia Journal of Arts Research and Education, 7(1), 62018.

Mori, F., Naghsh, F. A., \& Tezuka, T. (2014). The effect of music on the level of mental concentration and its temporal change. CSEDU 2014 - Proceedings of the 6th 
International Conference on Computer Supported Education, 1, 34-42. https://doi.org/10.5220/0004791100340042

Nasih, A M dan Kholidah, L N. (2009). Metode dan Tehnik Pembelajaran Pendidikan Agama Islam. Bandung: PT. Refika Aditama.

Panjaitan, D. J. (2020). Musik Mozart Sebagai Pengiring Pembelajaran Untuk Meningkatkan Motivasi dan Belajar Matematika. Jurnal MathEducation Nusantara, 3(1), 40-48.

Parikh, N. D. (2016). Effectiveness of Teaching through Mind Mapping Technique. The International Journal of Indian Psychology, 3(3), 148-156.

Ramadhona, R. (2016). Penggunaan Mind Map Diiringi Musik Klasik Dalam Pembelajaran Matematika Untuk Siswa Kelas Viii Smpn 1 Sawahlunto. Jurnal Pendidikan Matematika, 10(2), 1-7. https://doi.org/10.22342/jpm.10.2.3636.87-92

Rohyatun, R. (2018). Upaya Meningkatkan Motivasi Dan Hasil Belajar Peserta Didik Kelas VI Dengan Menerapkan Model Dua Tinggal Dua Tamu Di SD Negeri 27 Ampenan Semester Dua Tahun Pelajaran 2017/2018. JISIP (Jurnal Ilmu Sosial Dan Pendidikan), 2(2).

Suryani, M. Syauqi, P. D. M. (2017). Improving Students ' Reading Comprehension Improving Students ' Reading Comprehension. (November), 315-318.

Susanti, L. B., Poedjiastoeti, S., \& Taufikurohmah, T. (2018). Validity of worksheet-based guided inquiry and mind mapping for training students' creative thinking skills. Journal of Physics: Conference Series, 1006(1). https://doi.org/10.1088/17426596/1006/1/012015

Tony, B. (2006). BukuPintar Mind Map.Jakarta: GramediaPustakaUtama. Hal 4-12.

Waloyo, E. (2017). the Implementation of Mind Mapping Technique in Teaching Writing: a Case Study At Man 13 Jakarta. ELT Echo: The Journal of English Language Teaching in Foreign Language Context, 2(1), 72. https://doi.org/10.24235/eltecho.v2i1.1596

Wilson, K., Copeland Solas, E., \& Guthrie-Dixon, N. (2016). A Preliminary study on the use of Mind Mapping as a Visual-Learning Strategy, in General Education Science classes for Arabic speakers in the United Arab Emirates. Journal of the Scholarship of Teaching and Learning, 16(1), 31-52. https://doi.org/10.14434/josotl.v16i1.19181 